\title{
Biochemical Identification and Characterization of DNA Groups within the Proteus vulgaris Complex
}

\author{
J. MICHAEL JANDA,* SHARON L. ABBOTT, SHIDEH KHASHE, AND WILL PROBERT \\ Microbial Diseases Laboratory, Division of Communicable Disease Control, California Department of Health Services, \\ Berkeley, California 94704-1011
}

Received 23 October 2000/Returned for modification 29 December 2000/Accepted 12 January 2001

\begin{abstract}
We placed 43 isolates belonging to the Proteus vulgaris complex into proposed DNA groups (genomovars) using five previously recommended tests (tests for esculin hydrolysis, production of acid from salicin, Lrhamnose fermentation, and elaboration of DNase and lipase). On the basis of the results of these five tests, $49 \%$ of the isolates fell into DNA groups 5 and 6, 37\% fell into DNA group 2, and the remaining 14\% fell into DNA groups 3 and 4. Sequencing of the 16S rRNA genes of 11 members of DNA groups 5 and 6 indicated that 10 of these isolates $(91 \%)$ could be unambiguously assigned to one of these two genomospecies. Overall expression of selected enzymatic and virulence-associated characteristics did not differ significantly among DNA groups.
\end{abstract}

Over the past two decades the genus Proteus, and in particular Proteus vulgaris, has undergone a number of major taxonomic revisions (11). In a groundbreaking study conducted at the Centers for Disease Control and Prevention in 1978, it was concluded that the species $P$. vulgaris was genetically heterogeneous at the DNA level (2). In 1982, Hickman and others (3) identified three biogroups within $P$. vulgaris on the basis of indole production, esculin hydrolysis, and fermentation of salicin. Biogroup 1 strains, which were indole negative, were found to represent a new species, and the name $P$. penneri was proposed (3). Biogroups 2 and 3, however, remained within the species $P$. vulgaris.

Recently, Mohr O'Hara and others (12) have determined by DNA-DNA hybridization that biogroup 2 strains of $P$. vulgaris represent a separate genomospecies. In contrast, biogroup 3 strains were found be genetically heterogeneous. Four distinct groups could be distinguished within biogroup 3 strains, each of which was found to represent a new genomospecies. Although early studies suggested that all of these groups could be phenotypically distinguished from one another with the exception of DNA groups 5 and 6 (1), later investigations by the same investigators showed that DNA groups 4 and 5 could not be unambiguously separated from one another on the basis of acid production from L-rhamnose (12). One problem stemming from these results was the fact that the current type strain of $P$. vulgaris (strain NCTC 4175) resided in DNA group 3. This group is composed of only two strains and is not biochemically representative of the majority of $P$. vulgaris isolates identified in clinical laboratories. On the basis of these observations, Brenner and associates (1) submitted a request for an opinion to replace the current type strain of $P$. vulgaris, NCTC 4175 (ATCC 13315), with ATCC 29905 (biogroup 2). In 1999 the Judicial Commission of the International Committee on Systematic Bacteriology ruled that NCTC 4175, used as the

\footnotetext{
* Corresponding author. Mailing address: Microbial Diseases Laboratory, 2151 Berkeley Way, Berkeley, CA 94704-1011. Phone: (510) 540-2242. Fax: (510) 540-2374. E-mail: jjanda@dhs.ca.gov.
}

neotype strain of $P$. vulgaris, should be replaced with strain ATCC 29905 (9). Subsequent to this decision, the name $P$. hauseri sp. nov. has been proposed for strains previously assigned to $P$. vulgaris genomospecies 3 (12).

Since publication of the reports of Brenner et al. (1) and Mohr O'Hara et al. (12), no studies on the utility of the proposed biochemical tests for separation of these recently described genomospecies within $P$. vulgaris have been published. In this report we describe the characterization of $43 P$. vulgaris strains to the DNA group level, their relative frequencies in clinical material, and whether potential virulence factors could be ascribed to distinct genomospecies.

\section{MATERIALS AND METHODS}

Strains. A total of $43 P$. vulgaris strains were included in the present study. All strains were maintained as working cultures on motility deeps as described previously (6). The majority of these strains were kindly provided by David Bruckner (University of California, Los Angeles, Medical Center, Los Angeles), Richard B. Clark (American Medical Laboratories, Chantilly, Va.), Marie B. Coyle (Harborview Medical Center, Seattle, Wash.), Peter Gilligan (University of North Carolina Hospitals, Chapel Hill), Larry D. Gray (Bethesda North Hospital, Cincinnati, Ohio), Tim Kiehn (Sloan Kettering Memorial Center, New York, N.Y.), Patrick R. Murray (Washington University School of Medicine, St. Louis, Mo.), Timothy L. Overman (Veterans Affairs Medical Center, Lexington, Ky.), Barth Reller (Duke University Medical Center, Durham, N.C.), David Sewell (Veterans Affairs Medical Center, Portland, Oreg.), and Ken Van Horn (Westchester County Health Care Corp., Valhalla, N.Y.).

Biochemical identification. All strains included in this study possessed biochemical properties consistent with inclusion in the genus Proteus: positivity for phenylalanine deaminase, production of a reddish brown pigment on DL-tryptophan agar, degradation of L-tyrosine crystals, swarming on solid media, $\mathrm{H}_{2} \mathrm{~S}$ production on triple sugar iron agar slants, gelatinase activity, and fermentation of D-mannose (4). Isolates were further identified as members of the $P$. vulgaris complex on the basis of indole production, lack of ornithine decarboxylase activity, and production of acid from maltose fermentation. Medium compositions and testing procedures have been described previously (7).

$P$. vulgaris strains were typed and placed in to DNA groups as reported by Brenner et al. (1) and Mohr O'Hara et al. (12) by the following biochemical tests: esculin hydrolysis, elaboration of DNase, elaboration of corn oil lipase, and acid production from $\mathrm{L}$-rhamnose and salicin. The test samples were incubated for a maximum of $72 \mathrm{~h}$ at $35^{\circ} \mathrm{C}$, with results recorded daily. The reference strains used in these studies include $P$. vulgaris ATCC 29905 (DNA group 2) and $P$. hauseri ATCC 13315 (NCTC 4175; DNA group 3), ATCC 51469 (DNA group 4), ATCC 51470 (DNA group 5), and ATCC 51471 (DNA group 6). 
16S rRNA sequencing. For each $P$. vulgaris strain, a 1- $\mu$ l loopful of solid growth was extracted and the DNA was purified with the DNeasy Tissue kit (Qiagen Inc., Valencia, Calif.) according to the manufacturer's recommendation. A 529-bp segment from the $5^{\prime}$ end of the 16S rRNA gene (rDNA) was amplified from the $P$. vulgaris DNA with broad-range primers 0005F and 0531R (14). The PCR mixture consisted of $50 \mathrm{ng}$ of $P$. vulgaris DNA, 25 pmol of each primer, 2.5 $\mathrm{mM} \mathrm{MgCl} 2,200 \mu \mathrm{M}$ deoxynucleoside triphosphates, and 1 Unit of AmpliTaq Gold DNA polymerase. To initiate the PCR, the DNA polymerase was activated by incubation of the reaction mixture for $10 \mathrm{~min}$ at $95^{\circ} \mathrm{C}$. The $\mathrm{PCR}$ conditions consisted of a denaturation step of $30 \mathrm{~s}$ at $94^{\circ} \mathrm{C}$, an annealing step of $30 \mathrm{~s}$ at $60^{\circ} \mathrm{C}$, and an extension step of $1 \mathrm{~min}$ at $72^{\circ} \mathrm{C}$ for a total of 35 cycles. A final extension step was performed for $7 \mathrm{~min}$ at $72^{\circ} \mathrm{C}$. The amplification products were purified with QIAquick spin columns (Qiagen Inc.). Cycle sequencing of the amplification products was performed by dye terminator chemistry (Applied Biosystems, Foster City, Calif.), with both strands of the amplification product being sequenced with the primers described above. The cycle sequencing products were analyzed on an ABI 377 DNA sequencer, and sequence assembly and analysis were accomplished with MicroSeq Analysis software (Applied Biosystems). P. vulgaris strains were assigned to a specific DNA group if there was less than $0.7 \% 16 \mathrm{~S}$ rDNA sequence divergence between the test isolate and the reference strain (the American Type Culture Collection [ATCC] strain) for a given genomospecies.

Enzymatic and virulence-associated characteristics. All 43 P. vulgaris complex isolates were evaluated for the expression of constitutive phosphatase, esterase, arylamidase, and glucosidase activities by the API ZYM test (bioMérieux, Hazelwood, Mo.) according to the manufacturer's instructions. In addition, representative strains of each $P$. vulgaris DNA group were evaluated further for certain enzymatic or virulence-associated properties. These included production of chitinase, stapholysin, phosphatase, mucinase, butyrase, esterase, hyaluronidase, amylase, hemolysin, and alkylsulfastase activities; elaboration of a siderophore on Chrome Azurol S agar; and invasion of Vero cells. The test procedures and control strains for these tests have been described previously (5-8).

\section{RESULTS}

Forty-seven strains were initially received as $P$. vulgaris. Of these isolates, three were subsequently identified as $P$. mirabilis and a fourth strain was found not to be a member of the genus Proteus. Of the remaining 43 strains, 37 originated from clinical material. The sources of these 37 clinical isolates were urine $(n=15)$, wounds $(n=12)$, blood $(n=7)$, sputum $(n=2)$, and unspecified $(n=1)$. Six animal isolates of $P$. vulgaris were also included in this survey; four strains were recovered from snakes, and one strain each was recovered from a lizard and a mouse.

An attempt was then made to place these $43 P$. vulgaris strains into representative DNA groups on the basis of the published biochemical properties associated with specific genomovars (1). In the original reports of O'Hara et al. (C. O'Hara, F. Hickman-Brenner, A. Steigerwalt, B. Hill, B. Holmes, P. Grimont, P. Hawkey, J. Penner, J. M. Miller, and D. J. Brenner, Abstr. 94th Gen. Meet. Am. Soc. Microbiol. 1994, abstr. C-253, 1994) and Brenner et al. (1), seven tests were used to differentiate $P$. vulgaris isolates into DNA groups $2,3,4$, and $5-6$. In preliminary studies, we found two of these tests (those for acetate and tartrate utilization) to be of limited value. Most strains were acetate positive $(77 \%)$, and the test yielded little discriminatory value. Tartrate reactions were difficult to read, and so we decided not to use this reaction. Therefore, assignment of individual $P$. vulgaris strains to genomovars was based on the results of the five tests listed in Table 1.

Table 2 lists the distribution of $43 P$. vulgaris strains by DNA group and source of isolation. All 43 P. vulgaris isolates could be easily placed into one of four DNA groups on the basis of the results of the biochemical tests listed in Table 1 . The results of virtually all tests with the exception of that for DNase activity were positive within $24 \mathrm{~h}$; in the test for DNase activity,
TABLE 1. Identification of $P$. vulgaris strains to DNA group level by biochemical methods

\begin{tabular}{lcccc}
\hline \multirow{2}{*}{ Test } & \multicolumn{5}{c}{$\begin{array}{c}\text { Result for the following } P \text {. vulgaris } \\
\text { DNA group }\end{array}$} \\
\cline { 2 - 5 } & Group 2 & Group 3 & Group 4 & Group 5/6 \\
\cline { 2 - 5 } & + & - & - & - \\
Esculin hydrolysis & & & & - \\
Acid production from: & + & - & - & - \\
$\quad$ Salicin & - & - & + & + \\
L-Rhamnose & $\mathrm{V}$ & - & + & $\mathrm{V}$ \\
Corn oil lipase elaboration & + & - & + & + \\
DNase elaboration & & &
\end{tabular}

${ }^{a}$ Symbols and abbreviation:,$+>85 \%$ positive;,$-<15 \%$ positive; $v$, variable (11 to $85 \%$ positive).

$\sim 20 \%$ of strains tested gave a delayed ( $>24-\mathrm{h}$ ) reaction. Of the 43 strains typed, 21 (49\%) belonged to DNA group 5 or 6,16 $(37 \%)$ belonged to DNA group 2, $4(9 \%)$ belonged to DNA group 4 , and $2(5 \%)$ belonged to DNA group 3. There were no obvious differences in the distributions of $P$. vulgaris strains assigned to DNA groups by source.

Although initial studies conducted by the Centers for Disease Control and Prevention found that acid production from L-rhamnose was a distinguishing feature of DNA group 4 strains (1), a later study by the same group of investigators found $17 \%$ of DNA group 5 isolates to be L-rhamnose positive (12); $60 \%$ of DNA group 4 strains $(n=5)$ also produced acid from $\alpha$-methyl-D-glucoside, while none of the DNA group 5 isolates $(n=18)$ did so. We therefore further characterized the four strains biochemically assigned to DNA group 4 (Table 2). As can be seen from the results presented in Table 3, all four strains were rhamnose positive and $\alpha$-methyl-D-glucoside negative. Three of these four strains were confirmed to be members of DNA group 4 by $16 \mathrm{~S}$ rDNA analysis. The fourth strain, PV-27, a wound isolate, was clearly shown to be a member of DNA group 5 by $16 \mathrm{~S}$ rDNA sequencing.

Because DNA groups 5 and 6 cannot be phenotypically distinguished from each other, we investigated whether $11 P$. vulgaris strains assigned to DNA groups 5 and 6 could be separated from each other by analyzing a 529-bp region of the $16 \mathrm{~S}$ rDNA. The results are presented in Table 4. Of the 11 strains analyzed, 10 could be tentatively assigned to either DNA group 5 or 6 on the basis of $16 \mathrm{~S}$ sequence divergence. Of these 10 strains, 6 were assigned to DNA group 5 and 4 were assigned to DNA group 6; all 4 DNA group 6 strains were from wounds. The single remaining isolate, PV-34, could not be

TABLE 2. Distribution of 43 P. vulgaris strains by DNA group and source of isolation

\begin{tabular}{lccccc}
\hline \multirow{2}{*}{\multicolumn{1}{c}{ Source }} & Total & \multicolumn{4}{c}{ No. of strains in $P$. vulgaris DNA group: } \\
\cline { 3 - 6 } & & Group 2 & Group 3 & Group 4 & Group 5/6 \\
\hline Urine & 15 & 4 & 2 & 2 & 7 \\
Wound or abscess & 12 & 3 & 0 & 2 & 7 \\
Blood & 7 & 3 & 0 & 0 & 4 \\
Animals & 6 & 4 & 0 & 0 & 2 \\
Sputum & 2 & 2 & 0 & 0 & 0 \\
Unknown & 1 & 0 & 0 & 0 & 1 \\
\multicolumn{1}{c}{ Total } & 43 & 16 & 2 & 4 & 21 \\
\hline
\end{tabular}


TABLE 3. Comparative 16S rDNA sequence divergence of rhamnose-positive DNA group 4 P. vulgaris strains

\begin{tabular}{cccccc}
\hline \multirow{2}{*}{$\begin{array}{c}\text { Strain } \\
\text { no. }\end{array}$} & \multicolumn{2}{c}{ Acid production from: } & & \multicolumn{2}{c}{ Sequence divergence (\%) relative to: } \\
\cline { 2 - 4 } & L-Rhamnose & $\begin{array}{c}\alpha \text {-Methyl-D- } \\
\text { glucoside }\end{array}$ & & $\begin{array}{c}\text { Group 4 } \\
\text { (ATCC 51469) }\end{array}$ & $\begin{array}{c}\text { Group 5 } \\
\text { group } \\
\text { assignment }\end{array}$ \\
\hline PV-14 & + & - & 0.09 & 1.61 \\
PV-17 & + & - & 0.57 & 1.14 & 1.52 \\
PV-20 & + & - & 0.19 & 4 \\
PV-27 & + & - & 1.33 & 0.38 \\
\hline
\end{tabular}

unambiguously assigned to either DNA group on the basis of the $16 \mathrm{~S}$ rDNA test results. This strain had typical phenotypic properties associated with DNA groups 5 and 6 except that it was lipase negative and the DNase reaction was delayed $(72 \mathrm{~h})$.

All 43 P. vulgaris strains were evaluated for enzymatic activity by the API ZYM test. Ten enzymes were absent from all strains tested: valine arylamidase, cystine arylamidase, chymotrypsin, $\alpha$-galactosidase, $\beta$-galactosidase, $\beta$-glucuronidase, $\beta$-glucosidase, $N$-acetyl- $\beta$-glucosaminidase, $\alpha$-mannosidase, and $\alpha$ fucosidase. The remaining enzymatic activities were present in some or all of the P. vulgaris strains tested (Table 5). Overall, the strongest enzymatic activities (relative values, $>4.0$ ) recorded were for alkaline and acid phosphatase, leucine arylamidase, and naphthol-AS-BI-phosphohydrolase. Weak esterase, lipase, trypsin, and $\alpha$-glucosidase activities (relative activity, $<2.0$ ) were detected in $P$. vulgaris strains from some DNA groups. The relative enzymatic activities appeared to be fairly constant across DNA groups, with only minor differences noted in regard to trypsin and $\alpha$-glucosidase.

Some Proteus species, notably $P$. mirabilis, have several virulence-associated characteristics including hemolysin production (10) and the ability to invade Vero cells (13). We therefore tested several representative strains of each $P$. vulgaris DNA group for similar activities. All $P$. vulgaris strains with the exception of a group 3 isolate produced a cell-associated hemolysin. No strain tested invaded either HEp-2 or Vero cells; the proportions of residual gentamicin-resistant progeny from invasion assays ranged from 0.009 to $0.04 \%$ of the initial inoculum. All $P$. vulgaris strains tested were negative for the stxl, stx2, and eae genes by PCR (5) and for siderophores, chitinase,

TABLE 4. Comparative 16S rDNA sequence divergence of $P$. vulgaris group 5 and 6 strains

\begin{tabular}{|c|c|c|c|c|}
\hline \multirow{2}{*}{ Strain no. } & \multirow{2}{*}{ Source } & \multicolumn{2}{|c|}{$\begin{array}{c}\text { Sequence divergence }(\%) \\
\text { relative to: }\end{array}$} & \multirow{2}{*}{$\begin{array}{c}\text { DNA } \\
\text { group } \\
\text { assignment }\end{array}$} \\
\hline & & $\begin{array}{c}\text { Group } 5 \\
\text { (ATCC 51470) }\end{array}$ & $\begin{array}{c}\text { Group } 6 \\
\text { (ATCC 51471) }\end{array}$ & \\
\hline PV-2 & Urine & 0.38 & 1.70 & Group 5 \\
\hline PV-6 & Blood & 0.38 & 1.32 & Group 5 \\
\hline PV-7 & Blood & 0.19 & 1.51 & Group 5 \\
\hline PV-12 & Wound & 1.32 & 0.38 & Group 6 \\
\hline PV-13 & Urine & 0.57 & 1.51 & Group 5 \\
\hline PV-25 & Wound & 1.70 & 0 & Group 6 \\
\hline PV-28 & Wound & 0.38 & 1.32 & Group 5 \\
\hline PV-29 & Wound & 1.32 & 0.38 & Group 6 \\
\hline PV-31 & Wound & 1.51 & 0.19 & Group 6 \\
\hline PV-34 & Wound & 1.13 & 0.95 & $\mathrm{ND}^{a}$ \\
\hline PV-42 & Mouse & 0 & 1.70 & Group 5 \\
\hline
\end{tabular}

${ }^{a} \mathrm{ND}$, could not be determined. stapholysin, mucinase, chondroitinase, and alkylsulfatase by plate assay.

\section{DISCUSSION}

The results of the present survey confirm the previous findings of Brenner et al. (1) in regard to the frequency of occurrence of different DNA groups in clinical specimens. In the study of Brenner et al. (1), in which the vast majority of isolates were of human origin, DNA groups 5 and 6 accounted for $81 \%$ (29 of 36) of $P$. vulgaris biogroup 3 strains. Among 29 DNA group 5 and 6 strains, $18(62 \%)$ were determined to reside within DNA group 5 by DNA-DNA hybridization (1). Genomospecies 3 and 4 accounted for the remaining 19\% of the strains. In the present investigation, we found that only 5 of 43 (12\%) P. vulgaris strains belonged to genomospecies 3 and 4 . These results and those from a previous study (1) indicate that strains of DNA groups 2, 5, and 6 predominate in clinical specimens, while strains of groups 3 and 4 are encountered less frequently. The $16 \mathrm{~S}$ rDNA sequencing results for 10 group 5-6 strains also support the higher prevalence of DNA group 5 over DNA group 6 strains previously reported by Brenner et al. (1). However, one strain (PV-34) which was phenotypically identified as a group 5-6 strain could not be unambiguously assigned to either group on the basis of its $16 \mathrm{~S}$ rDNA sequence. Possible explanations include the possibility that PV-34 belongs to a genomospecies other than group 5 or 6 or that $16 \mathrm{~S}$ rDNA sequencing is unable to be as discriminatory as DNA hybridization in all instances. We also found no obvious differences in the site of isolation (e.g., blood or stool) or the enzymatic properties of strains assigned to specific DNA groups. The facts that all DNA group 6 strains originated from

TABLE 5. Enzymatic activities of $P$. vulgaris DNA groups

\begin{tabular}{lllll}
\hline \multirow{2}{*}{\multicolumn{1}{c}{ Enzyme }} & \multicolumn{4}{c}{ Avg relative activity for the following $P$. vulgaris } \\
& \multicolumn{4}{c}{ DNA group: } \\
\cline { 2 - 5 } & \multicolumn{1}{c}{ Group 2 } & Group 3 & Group 4 & Group 5/6 \\
\hline Alkaline phosphatase & $5.0(100)^{a}$ & $5.0(100)$ & $5.0(100)$ & $4.95(100)$ \\
$\mathrm{C}_{4}$ esterase & $0.13(13)$ & $0.5(50)$ & $1.0(75)$ & $0.57(48)$ \\
$\mathrm{C}_{8}$ esterase & $0.06(6)$ & 0 & $1.0(75)$ & $0.29(19)$ \\
$\mathrm{C}_{14}$ lipase & 0 & 0 & $1.0(50)$ & $0.24(19)$ \\
Leucine arylamidase & $4.93(100)$ & $5.0(100)$ & $5.0(100)$ & $4.9(100)$ \\
Trypsin & $0.69(31)$ & 0 & $1.5(100)$ & $1.14(67)$ \\
Acid phosphatase & $5.0(100)$ & $5.0(100)$ & $5.0(100)$ & $4.95(100)$ \\
Naphthol-AS-BI- & $4.25(100)$ & $5.0(100)$ & $4.75(100)$ & $4.19(100)$ \\
$\quad$ phosphohydrolase & & & & \\
$\alpha-$ Glucosidase & $2.19(100)$ & 0 & $2.75(100)$ & $1.38(100)$ \\
\hline
\end{tabular}

${ }^{a}$ Values in parentheses are the percentage of strains in each DNA group expressing enzymatic activity. 
wounds and that four of five DNA group 5 strains of clinical origin were from blood or urine (Table 4) suggest that some genomospecies may have a predilection for certain anatomic sites. However, there is no reason for clinical microbiologists working at the bench to change identification procedures regarding members of the $P$. vulgaris complex solely on the basis of recent taxonomic proposals and the limited amount of clinical information presently available concerning these new species and genomospecies.

\section{REFERENCES}

1. Brenner, D. J., F. W. Hickman-Brenner, B. Holmes, P. M. Hawkey, J. L. Penner, P. A. D. Grimont, and C. M. O'Hara. 1995. Replacement of NCTC 4175, the current type strain of Proteus vulgaris, with ATCC 29905. Request for an opinion. Int. J. Syst. Bacteriol. 45:870-871.

2. Brenner, D. J., J. J. Farmer III, G. R. Fanning, A. G. Steigerwalt, P. Klykken, H. G. Wathen, F. W. Hickman, and W. H. Ewing. 1978. Deoxyribonucleic acid relatedness of Proteus and Providencia species. Int. J. Syst. Bacteriol. 28:269-282.

3. Hickman, F. W., A. G. Steigerwalt, J. J. Farmer III, and D. J. Brenner. 1982. Identification of Proteus penneri sp. nov., formerly known as Proteus vulgaris indole negative or Proteus vulgaris biogroup 1. J. Clin. Microbiol. 15:10971102.

4. Janda, J. M., and S. L. Abbott. 1998. The enterobacteria. Lippincott-Raven, Philadelphia, Pa.

5. Janda, J. M., S. L. Abbott, and M. J. Albert. 1999. Prototypal diarrheagenic strains of Hafnia alvei are actually members of the genus Escherichia. J. Clin. Microbiol. 37:2399-2401.
6. Janda, J. M., S. L. Abbott, W. K. W. Cheung, and D. F. Hanson. 1994. Biochemical identification of citrobacteria in the clinical laboratory. J. Clin. Microbiol. 32:1850-1854.

7. Janda, J. M., S. L. Abbott, S. Khashe, and T. Robin. 1996. Biochemical investigations of biogroups and subspecies of Morganella morganii. J. Clin. Microbiol. 34:108-113.

8. Janda, J. M., S. L. Abbott, and L. S. Oshiro. 1991. Penetration and replication of Edwardsiella spp. in HEp-2 cells. Infect. Immun. 59:154-161.

9. Judicial Commission of the International Committee on Systematic Bacteriology. 1999. Replacement of strain NCTC 4175, since 1963 the neotype strain of Proteus vulgaris, with strain ATCC 29905-opinion 70. Int. J. Syst. Bacteriol. 49:1949.

10. Koronakis, V., M. Cross, B. Senior, E. Koronakis, and C. Hughes. 1987. The secreted hemolysins of Proteus mirabilis, Proteus vulgaris, and Morganella morganii are genetically related to each other and to the alpha-hemolysin of Escherichia coli. J. Bacteriol. 169:1509-1515.

11. Mohr O'Hara, C., F. W. Brenner, and J. M. Miller. 2000. Classification, identification, and clinical significance of Proteus, Providencia, and Morganella. Clin. Microbiol. Rev. 13:534-546.

12. Mohr O'Hara, C., F. W. Brenner, A. G. Steigerwalt, B. C. Hill, B. Holmes, P. A. D. Grimont, P. M. Hawkey, J. L. Penner, J. M. Miller, and D. J. Brenner. 2000. Classification of Proteus vulgaris biogroup 3 with recognition of Proteus hauseri sp. nov., nom. rev. and unnamed Proteus genomospecies 4, 5 and 6. Int. J. Syst. Evol. Microbiol. 50:1869-1875.

13. Peerbooms, P. G. H., A. M. Verweij, and D. M. MacLaren. 1984. Vero cell invasiveness of Proteus mirabilis. Infect. Immun. 43:1068-1071.

14. Tang, Y., N. M. Ellis, M. K. Hopkins, D. H. Smith, D. E. Dodge, and D. H. Persing. 1998. Comparison of phenotypic and genotypic techniques for identification of unusual aerobic pathogenic gram-negative bacilli. J. Clin. Microbiol. 36:3674-3679. 